COMmentary

Published March 14, 2017

\title{
Celebrating More Than a Century of RESEARCH ON ANTIBODIES: Affirmation Through Negation via Complex Formation
}

\section{AUTHOR}

Neil S. Greenspan ${ }^{1}$

AFFILIATED INSTITUTION

${ }^{1}$ Case Western Reserve University, Cleveland, Ohio

CORRESPONDING AUTHOR

DOI

Neil S. Greenspan

10.20411/pai.v2i1.198

nsg@,case.edu

\section{SUGGESTED CITATION}

Greenspan NS. Celebrating More Than a Century of Research on Antibodies: Affirmation Through Negation via Complex Formation. Pathogens and Immunity. 2017;2(1):60-65. doi: 10.20411/pai.v2i1.198

\section{ABSTRACT}

In this brief commentary, I highlight the remarkable properties of antibodies (also known as immunoglobulins) revealed by more than 100 years of biomedical research. Since antibodies can be elicited through one or another means against almost any molecule or macromolecule, the universe of antibodies represents a sort of molecular mirror for the totality of molecules that make life possible. Consequently, as recounted below, antibodies play a role in almost every aspect of medicine and biomedical research.

Keywords: antibody, immunoglobulin, affinity, complex formation, molecular discrimination, serum half-life, effector function, complementarity, gene rearrangement, somatic hypermutation, affinity maturation 


\section{CENTRAL QUESTION}

Over one hundred years after Emil Adolph (later von) Behring's discovery of serum factors that mediate immunity [1] earned the first Nobel Prize in Physiology or Medicine in 1901 [ㄹ] , why should we celebrate antibodies, what von Behring originally called "antikorper"? Why be concerned with heavy and light chains, variable and constant domains, Fabs and Fcs, hypervariable and framework regions, isotypes, allotypes, and idiotypes? What has "antibody," a term redolent with opposition, resounding with antagonism, resonating with subversion, come to signify?

\section{RANGE OF ANTIBODY FUNCTIONS}

Antibodies are functionally protean proteins [3] . They serve in an unparalleled range of roles in biology and medicine by virtue of a remarkable constellation of attributes including inducibility, or potential inducibility by, and noncovalent affinity for, almost any small molecule or macromolecule, prodigious capacity for molecular discrimination, structural and functional stability, remarkably extended serum half-life, structural features conducive to detection in laboratory assays, and biologically efficacious interactions, known as effector functions. These immunity-mediating effector systems involve complement and Fc receptor-bearing cells and more recently-discovered intracellular molecules.

\section{GENETIC ORIGINS AND DIVERSITY}

Antibodies, also known as immunoglobulins, originate in an almost unique process of gene rearrangement (the broad outlines and selected critical details of which are shared with their first cousins, the T-cell receptors) that depends on what might be referred to as a series of dynamic, approximately one-dimensional immunoglobulin gene jigsaw puzzles []. Each antibody polypeptide chain is constructed of 3 or 4 domains encoded by gene segments that are separated by intervening stretches of nucleotide sequence in the germline DNA and that become juxtaposed, prior to translation, by either DNA rearrangement or RNA splicing. These nucleic acid acrobatics generate new amino acid sequences, not originally encoded in the germline genome, in regions of the polypeptide chains referred to, with astonishing creativity, as variable regions. Superimposed on these mutation-generating events that are integral to the processes required for the assembly of complete antibody-encoding genes is another unique process, termed somatic hypermutation that can lead to affinity maturation (ie, increased average affinity for the antigen) [ㅁ]. The latter process, effectively localized to the genetic sequences encoding heavy and light chain variable (V) domains, further expands the repertoire of $\mathrm{V}$ domain amino acid sequences displayed by the population of antibody molecules. As a consequence of these multiple diversification processes, there is enormous variation of primary structure in the context of impressive conservation of tertiary and quaternary structure. For example, a single human can produce as many as 100 billion different antibodies displaying distinguishable heavy-light chain V domain pairs [] ].

\section{COMPLEX FORMATION}

The complementary relationship between variation and conservation in antibody structure foreshadows the critical functional role of another level of complementarity. Antibodies exist in large measure to form noncovalent complexes with ligands, referred to as antigens, and it is through this fundamental biochemical process that vertebrate bodily integrity is affirmed and parasitic ambition is thwarted. At least to a rough approximation, the antibody and the antigen fit together 
as do the complementary shapes of a three-dimensional jigsaw puzzle $[\underline{7}, \underline{8}]$. However, intra-molecular flexibility in potentially both the antibody and the antigen, solvent effects, and other factors (eg, temperature, pressure, $\mathrm{pH}$, ionic strength, and the extent of molecular crowding) external to the antibody-antigen system can influence the strength of the interaction [9]. By virtue of these features, antibody-antigen interactions serve as instructive prototypes for all noncovalent interactions in biology.

\section{DIVERSITY OF MOLECULAR TARGETS}

Antibodies can bind to molecules in solution and on cell surfaces. They can recognize proteins (including other antibodies), peptides, polysaccharides, lipids, nucleic acids, and small organic molecules, natural or synthetic and including pharmaceutical agents. They can be elicited by and form non-covalent complexes with native, post-translationally modified, and denatured proteins. They can bind independently of one another, and they can bind via cooperative mechanisms, both inter-molecular and intra-molecular and can attach to monovalent and multivalent antigens. In addition, antibodies can sometimes engage all of their antigen-binding sites simultaneously with one bivalent or multivalent antigen, so called monogamous bivalency or multivalency, or they can crosslink independent soluble antigens or antigenic particles leading to, respectively, precipitation or agglutination. Both of these processes can be usefully exploited in research or clinical labs in addition to contributing to both physiologic and pathophysiologic mechanisms [10].

\section{MEDIATION OF IMMUNITY}

What beneficial consequences does this capacity for forming molecular complexes bring to the producer of the antibodies? Antibodies mediate immunity by diverse means. They inactivate toxins and enzymes and perhaps antagonize other functions associated with pathogen-encoded macromolecules. They do it by denying viruses the opportunity to latch onto, penetrate, or control the biosynthetic processes of host cells. They do it by preventing bacteria, fungi, and parasites from adhering to host epithelium, and by calling in other soluble molecules, such as the complement proteins, or cell-bound molecules, the Fc receptors and their associated cells, to destroy the targets to which they have physically attached: truly guilt by association. And, they may even do it, although perhaps less frequently, by following microbes into host cells and inactivating key pathogen molecules, or by transmitting healing signals into host cells [ㅍ].

\section{ROLES IN PATHOGENESIS}

As if this were not enough, antibodies also participate in disease pathogenesis through an equally varied range of mechanisms [10]. They can inactivate host hormones and kill, in concert with other host molecules, host cells. They can deposit in and damage tissues by eliciting the constellation of processes known as inflammation, and they can modulate inflammation as a function of their glycosylation state. They can also mimic hormones by binding to hormone receptors thereby transducing signals into cells and causing, in some cases, excessive secretion of yet other hormones, and they can decrease cell surface receptor expression, leading to failures in intercellular communication. Lastly, antibodies can contribute to the failure of almost any organ, including those newly acquired through transplantation [11]. 


\section{CONTRIBUTIONS TO DIAGNOSIS AND THERAPY}

And yet there is more to elicit the envy and subvert the self-esteem of other, less versatile, molecular species. In clinical laboratories, antibodies are used to measure the concentrations in body fluids of dozens of soluble molecules, from hormones and cytokines to toxins and drugs, both legal and illegal, to detect and characterize molecules in body fluids or tissues, and to identify and enumerate normal and abnormal cell types in the blood or tissues [12]. They have been used to compute compatibility for organ and stem cell transplants [13], detoxify overdoses of therapeutic drugs [14], pinpoint paternity [15], maintain maternity [16], and as products of biotechnology, treat tumors, infections, and immune responses that damage transplanted organs $[\underline{17}, \underline{18}]$. Coupled to radionuclides, and in conjunction with sophisticated imaging equipment, they can be used to localize antigens and cells in the living patient [19].

\section{CELL BIOLOGY AND SOMATIC EVOLUTION}

Antibodies exist in solution and on cell surfaces. They participate in signal transduction, antigen internalization, and cellular trafficking. They traverse epithelial surfaces, going from basolateral to apical domains, sometimes even disposing of molecular refuse in the process. They naturally evolve in real time in the course of a single host-pathogen interaction [20], and they can even be "trained" (via mutation and selection, in vivo or in vitro) to carry out selected enzymatic reactions $[\underline{21}, \underline{22}]$.

\section{MOTIVATION FOR FOCUSING ON ANTIBODIES}

So, here is an answer to the initial query: antibodies are pillars of the immune response, paragons of molecular specificity, defenders of organismal integrity, tools of diagnosis, purveyors of biotechnological therapy, and finally, as a consequence of the foregoing, emblems and icons of the immune system. If, as Richard Feynman claimed, "Nature uses only the longest threads to weave her patterns, so that each small piece of her fabric reveals the organization of the entire tapestry," then antibodies correspond to a very long thread indeed.

\section{ACKNOWLEDGMENTS}

I would like to thank Michael Lederman for encouraging submission of this manuscript and Michael Lederman and Don Anthony for critical comments and the numerous investigators whose research generated the insights summarized above.

\section{POTENTIAL CONFLICTS OF INTEREST}

The author does not have a conflict to declare.

\section{FINANCIAL SUPPORT}

Supported by funds from the CWRU/UH Center for AIDS Research: NIH Center for AIDS Research grant P30 AI036219. 


\section{REFERENCES}

1. Behring E, Kitasato S: Ueber das Zustandekommen der Diphtherie-Immunitat und der Tetanus-Immunitat bei thieren. Deutsche medizinsche Wochenschrift 1890; 16:1145-1148.

2. Emil von Behring - Biographical. Nobelprize.org: Nobel Media AB 2014; 2014 [cited 2017 March 13]. Available from: http://www.nobelprize.org/nobel_prizes/medicine/ laureates/1901/behring-bio.html.

3. Schroeder HW Jr., Wald D, and Greenspan NS. Immunoglobulins: structure and function. In: Fundamental Immunology, Seventh Edition, Paul, William E. (Editor), Wolters Kluwer/Lippincott Williams and Wilkins, Philadelphia, 2012, pp. 129-149.

4. Hozumi N, Tonegawa S. Evidence for somatic rearrangement of immunoglobulin genes coding for variable and constant regions. Proc Natl Acad Sci U S A. 1976;73(10):3628-32. PubMed PMID: 824647. PubMed Central PMCID: PMC431171.

5. Weigert MG, Cesari IM, Yonkovich SJ, Cohn M. Variability in the lambda light chain sequences of mouse antibody. Nature. 1970;228(5276):1045-7. PubMed PMID: 5483159.

6. Murphy K, Travers P, and Walport M. Janeway's Immunobiology, Seventh Edition, Garland Science, New York and London, 2008, p. 144.

7. Amit AG, Mariuzza RA, Phillips SE, Poljak RJ. Three-dimensional structure of an antigen-antibody complex at 2.8 A resolution. Science. 1986;233(4765):747-53. PubMed PMID: 2426778.

8. Davies DR, Cohen GH. Interactions of protein antigens with antibodies. Proc Natl Acad Sci U S A. 1996;93(1):7-12. Review. PubMed PMID: 8552677; PubMed Central PMCID: PMC: 40169.

9. Greenspan NS. Affinity, complementarity, cooperativity, and specificity in antibody recognition. Curr Top Microbiol Immunol. 2001;260:65-85. PubMed PMID: 11443882 .

10. Greenspan NS, Cavacini LA. Chapter 14, Immunoglobulin function. In: Clinical Immunology: Principles and Practice, Fourth Edition, Rich, R.R. (Editor- in-Chief); Elsevier Saunders, Philadelphia, 2013, pp. 183-192.

11. Colvin RB, Smith RN. Antibody-mediated organ-allograft rejection. Nat Rev Immunol. 2005;5(10):807-17. PubMed PMID: 16175181.

12. Part 11: Diagnostic Immunology In: Clinical Immunology: Principles and Practice, Fourth Edition, Rich, R.R. (Editor-in-Chief); Elsevier Saunders, Philadelphia, 2013, pp. 1145-1201.

13. Terasaki PI, Bernoco D, Park MS, Ozturk G, Iwaki Y. Microdroplet testing for HLA-A, -B, -C, and -D antigens. The Phillip Levine Award Lecture. Am J Clin Pathol. 1978;69(2):103-20. Review. PubMed PMID: 75690.

14. Ujhelyi MR, Robert S. Pharmacokinetic aspects of digoxin-specific Fab therapy in the management of digitalis toxicity. Clin Pharmacokinet. 1995;28(6):483-93. Review. 
PubMed PMID: 7656506. doi: 10.2165/00003088-199528060-00006

15. Schanfield MS. Application of immunoglobulin heavy chain (GM, AM) and light chain (KM) allotypes to cases of disputed paternity. Exp Clin Immunogenet. 1989;6(1):112-22. PubMed PMID: 2629883.

16. Hendrickson JE, Delaney M. Hemolytic Disease of the Fetus and Newborn: Modern Practice and Future Investigations. Transfus Med Rev. 2016;30(4):159-64. PubMed PMID: 27397673. doi: 10.1016/j.tmrv.2016.05.008.

17. Jetanalin P, Lee SJ, Kavanaugh A. Chapter 92, Biologic modifiers of inflammatory diseases. In: Clinical Immunology: Principles and Practice, Fourth Edition, Rich, R.R. (Editor-in-Chief); Elsevier Saunders, Philadelphia, 2013, pp. 1131-1142.

18. Yeung MY, Gabardi S, Sayegh MH. Use of polyclonal/monoclonal antibody therapies in transplantation. Expert Opin Biol Ther. 2017;17(3):339-352. PubMed PMID: 28092486. doi: 10.1080/14712598.2017.1283400.

19. Bailly C, Cléry PF, Faivre-Chauvet A, Bourgeois M, Guérard F, Haddad F, Barbet J, Chérel M, Kraeber-Bodéré F, Carlier T, Bodet-Milin C. Immuno-PET for Clinical Theranostic Approaches. Int J Mol Sci. 2016;28;18(1). pii: E57. PubMed PMID: 28036044; PubMed Central PMCID: PMC5297692. doi: 10.3390/ijms18010057.

20. Liao HX, Lynch R, Zhou T, Gao F, Alam SM, Boyd SD, Fire AZ, Roskin KM, Schramm CA, Zhang Z, Zhu J, Shapiro L; NISC Comparative Sequencing Program., Mullikin JC, Gnanakaran S, Hraber P, Wiehe K, Kelsoe G, Yang G, Xia SM, Montefiori DC, Parks R, Lloyd KE, Scearce RM, Soderberg KA, Cohen M, Kamanga G, Louder MK, Tran LM, Chen Y, Cai F, Chen S, Moquin S, Du X, Joyce MG, Srivatsan S, Zhang B, Zheng A, Shaw GM, Hahn BH, Kepler TB, Korber BT, Kwong PD, Mascola JR, Haynes BF. Co-evolution of a broadly neutralizing HIV-1 antibody and founder virus. Nature. 2013;496(7446):469-76. PubMed PMID: 23552890; PubMed Central PMCID: PMC3637846. doi: 10.1038/nature12053.

21. Hawkins RE, Russell SJ, Winter G. Selection of phage antibodies by binding affinity. Mimicking affinity maturation. J Mol Biol. 1992;226(3):889-96. PubMed PMID: 1507232.

22. Hanes J, Jermutus L, Weber-Bornhauser S, Bosshard HR, Plückthun A. Ribosome display efficiently selects and evolves high-affinity antibodies in vitro from immune libraries. Proc Natl Acad Sci U S A. 1998;95(24):14130-5. PubMed PMID: 9826665; PubMed Central PMCID: PMC24338.

\section{COPYRIGHT}

(C) Pathogens and Immunity 2017

This work is licensed under a Creative Commons Attribution 4.0 International License. To view a copy of this license, visit http://creativecommons.org/licenses/by/4.0/ 